\title{
Anatomical Votive Reliefs as Evidence for Specialization at Healing Sanctuaries in the Ancient Mediterranean World
}

\begin{abstract}
By Steven M. Oberhelman*
In the ancient Greek and Roman worlds, people flocked to the healing centers of various gods and goddesses for the cure of diseases and for relief from painful injuries and disabilities. The famous Greek healing god was Asclepius (in Rome called Aesculapius), but other gods had sanctuaries where suppliants could be healed-for example, in Greece Amphiareus, and in Italy Menvra, Diana, and Juno. After recovering health and wellbeing, grateful suppliants dedicated anatomical votive reliefs in the sanctuary to testify to the god's power. I will examine in this paper the thousands of anatomical reliefs found in the excavations of these sanctuaries. My purpose is to sketch out a map of healing centers that specialized in particular diseases. For example, it seems that of the Asclepian sanctuaries the one in Athens specialized in ocular diseases, while the cult center at Corinth was a place for patients with limb and appendage injuries and genital-urinary problems. In Italy, the cult at Ponte di Nona treated patients with foot and leg injuries as well as headaches and migraines, while other cult centers emphasized childbirth and gynecological matters. While the injured and the diseased in the classical world knew that many local healing centers were available to them, there were, as I will demonstrate, highly specialized centers of healing that they frequented. I will offer reasons for the specializations at certain centers (e.g., rural vs. urban lifestyles, environmental factors, local disease patterns, etc.).
\end{abstract}

\section{Introduction}

Medical anthropologists, employing an ethnographic approach to the social history of medicine, have shown that in a society there exists not a single medical system, but multiple systems. Individuals resort to one or another of these systems for a variety of reasons, such as economic means, accessibility of medical practitioners, the form of illness, the healer's past success or his reputation for dealing with specific ailments, and previous experiences of the patient and her family and friends. ${ }^{1}$ This sort of medical pluralism was

*Professor, Texas A\&M University, USA.

${ }^{1}$ See Oberhelman (2013, pp. 1-7) for bibliography and discussion. 
especially true of the ancient Greek and Roman worlds. ${ }^{1}$ In antiquity, there was little distinction between what we would label professional medicine and popular medicine. Greek medicine in the ancient world was a pluralism that included, of course, temple healing cults (especially that of Asclepius) and the formal medical practice of physicians like the Hippocratics and Galen. But other approaches to healing were available to the sick. One could self-treat, making use of the many herbs and plants in gardens or growing wild in the fields and mountains. Itinerant sellers of charms and incantations moved from village to village; many sold amulets and phylacteries for medical uses. Magicians offered hope to the sick through their spells; surviving Greek magical papyri offer help for many physical ailments through curative treatments that combine materia medica with magical names, magical, characters, and exorcism prayers. Midwives and other female healers practiced health care; most women in antiquity, in fact, probably received their maternity care from midwives. Root-cutters and drug-sellers were consulted, and it is not unlikely that most rural people saw them first for treatment. Finally, gymnastic trainers and dieticians dispensed medical advice, especially with regards to regimen, diet, and exercise. These various medical practitioners were not antagonists, but often overlapped in theory and praxis. Hippocratic writers possessed a religious outlook; they invoked the gods and called on their patronage, and recommended prayers as a useful companion to medical treatment. Professional doctors like Rufus of Ephesus and Galen accepted amulets. The pharmacology of ancient physicians and the great botanists includes magic and religion as well as good folk medicine, and in this respect we see nothing dissimilar in the Greek magical papyri, where we have many spells and incantations, amulets, and phylacteries directed toward healing. Some spells contain excellent medicinal ingredients, and even if the accompanying spoken incantation (which often included a jumble of Christian, Jewish, and pagan religious elements) and some extraneous or non-efficacious materials in the drug compound (e.g., nasal mucus, mule's earwax, menstrual blood) added nothing in a medical sense, some ingredients appear in the best ancient pharmacology.

\section{Ancient Greece}

All these various options for healing were accepted as valid by the people of the ancient world. The most popular venue for healing, however, was temple medicine. It was free, open to anyone of status or class or gender, and, if our texts and material evidence can be believed, quite successful. In ancient Greece and Italy, most gods possessed the power to heal, and the sick flocked to their sanctuaries for a cure or to pray for future health. In Greece, the most popular

${ }^{1}$ For more details regarding this paragraph, the reader is referred to Oberhelman (2013, pp. 830). 
healing sanctuary belonged to the god Asclepius. ${ }^{1}$ In his cult sick patients came and slept at night in a sleeping chamber. The god visited the sick person, and healed by direct intervention (laying on of hands, applying medicines, even performing surgery) or indirectly by sending a dream in which he recommended a treatment. The instructions in the latter case were often straight out of Hippocratic medicine: bloodletting, baths, diet, exercise, drugs, poultices, and emetics. Other deities like Apollo, Amphiareus, Artemis, Eileitheia, and Zeus healed at their own sacred cult places. In Italy healing sanctuaries are found everywhere along the western coast. ${ }^{2}$ Over 130 sites alone have been identified in central Italy from the fourth through second centuries B.C. The deities are Roman, Etruscan, and native Italic: for example, Apollo, Diana, Ceres, Liber, Jupiter, Juno, Minerva, Hercules, Mater Matuta, Mars Ultor, Vesta, Aesculapius, Venus, Turan, Castor and Pollux, Vesperna, Feronia, Dea Marica, Mercury, Lares, Vertumnus, Bacchus, Leda, Thesan, Tinia, Suris, and Mater Magna. ${ }^{3}$

Archaeologists have recovered at the healing shrines thousands of anatomical votive reliefs; these artifacts were dedicated by grateful patients for the healing of the body part which they received at the god's sanctuary. In Greece votive replicas of body parts have been found at the various Asclepian healing centers and other divine cult places. Some votives are made of terracotta; in the case of the city of Corinth, from the local clay and from workshops near the sanctuary. ${ }^{4}$ They were intended to be displayed on shelves, to hang on the temple walls, or to dangle from the ceiling. ${ }^{5}$ Votives like breasts, genitals, ears, and eyes contained holes for being hung, while heads and chests were flattened in the back so that they could rest on a shelf. Arms and legs, hands and feet, had holes at the top so that one could pass a thong through them and then hang them from ceiling hooks. Some cult centers contain lengthy inventory lists of the votive parts so that we have a good idea of the kinds of healing that went on there. ${ }^{6}$ In the Italian healing centers, four main types of sanctuaries have been identified: ${ }^{7}$ urban, where the center is placed within the confines of a town or city; extramural, or when the center is located just outside the walls or living quarters of a city); extra-urban, that is, when the center is found at the termini of two different cities' territory; and rural, or when the center served primarily the needs of the local farm populace. The Italian anatomical votive offerings are made of terracotta and range from swaddled babies to heads to limbs to internal organs. Archaeologists have discovered the votives buried, as a rule, in ditches or trenches within the sanctuary; apparently the votives were disposed of in a ritualistic, ceremonial way. Elsewhere the votives were dedicated to the deity by being placed against

\footnotetext{
${ }^{1}$ The best and most recent treatment is Versnel (2011, pp. 400-421), with good bibliography; see also Bilbija (2012, pp. 250-256).

${ }^{2}$ See Fenelli (1975), Steingräber (1981), Comella (1981).

${ }^{3}$ Söderlin( 2004, p.278).

${ }^{4}$ Roebuck (1951, p. 112).

${ }^{5}$ Roebuck (1951, p. 116).

${ }^{6}$ Van Straten (1981, p. 109); see the exhaustive inventory in Aleshire (1989).

${ }^{7}$ See Lesk Blomerus (1999, pp. 16-21), with her Appendix II.
} 
the sanctuary's walls, altar, or cult statue base, ${ }^{1}$ while a few cult centers contained pits that had been dug for the purpose of allowing patients to dedicate their votives in a ceremony for the god.

All these votive offerings allow us to form some interesting conclusions. Since we can assume that the remains represent some kind of representative sampling, then we can use the data to determine whether certain sanctuaries specialized in the treatment of disease and if so, then what types of ailments were treated; this, in turn, may allow us to recover what illness were endemic to the local populations.

At the sanctuary of Asclepius in the city of Corinth, we have votive offerings from the fifth and fourth centuries B.C.; the offerings were found in deposits from renovations to the sanctuary and, being therefore accidental survivors, probably represent only a small sampling of the many gifts that suppliants had left in the complex (Figure 1). The votives that we do have are very interesting in type and frequency. Appendages and limbs-hands and feet, arms and legs - constitute a majority of the findings; as an example, there alone are 145 hands. The high number of these body parts may be related directly to the suppliants' way of life: an agricultural or rural lifestyle, which involved, given the high number of feet, much walking. But the sanctuary is within the city walls and Corinth itself was one of the larger cities in ancient Greece, and so the sanctuary did not serve the people within the city itself. Instead, the offerings imply that suppliants came from the farming areas beyond Corinth and the smaller local villages. ${ }^{2}$ Also interesting are the numerous genitalia (52), many of them penises. Many of the penises display in their representation phimosis, which is the constriction of the opening of the foreskin so that it cannot be drawn back over the tip of the penis. ${ }^{3}$ The reason for so many such diseased penises is probably venereal disease, and here the city itself may be to blame. Corinth was well known in antiquity as a place of prostitution and rampant sexual immorality; it was also a famous harbor city and port of call for many ships. ${ }^{4}$ It may well be that the cult center at Corinth served as a healing place for sexually transmitted diseases, even those whose provenance was the city itself. There are also numerous female breasts (76), but their significance is not clear (Figure 2). I do not believe that the breasts imply that diseases like breast cancer were healed here; rather, suppliants may have dedicated the offerings either out of gratitude for the birth of a child or, more likely, as a request for pregnancy or good lactation.

\footnotetext{
${ }^{1}$ See Comella (2001, esp. pp. 131-148).

${ }^{2}$ Roebuck (1951, p. 128); however, the feet could represent the completion of a successful journey, just as ears may involve not otic disease but a request that the god will hear the suppliant's prayer.

${ }^{3}$ See the recent discussion in D'Arcy Dicus (2012, pp. 149-154), with bibliography on (p. 149). 149).

${ }^{4}$ The old notion that sacred prostitution was practiced at Corinth has been dispelled; see Budin (2008, chapter 6).
} 
Figure 1. Votive Offerings, Corinth

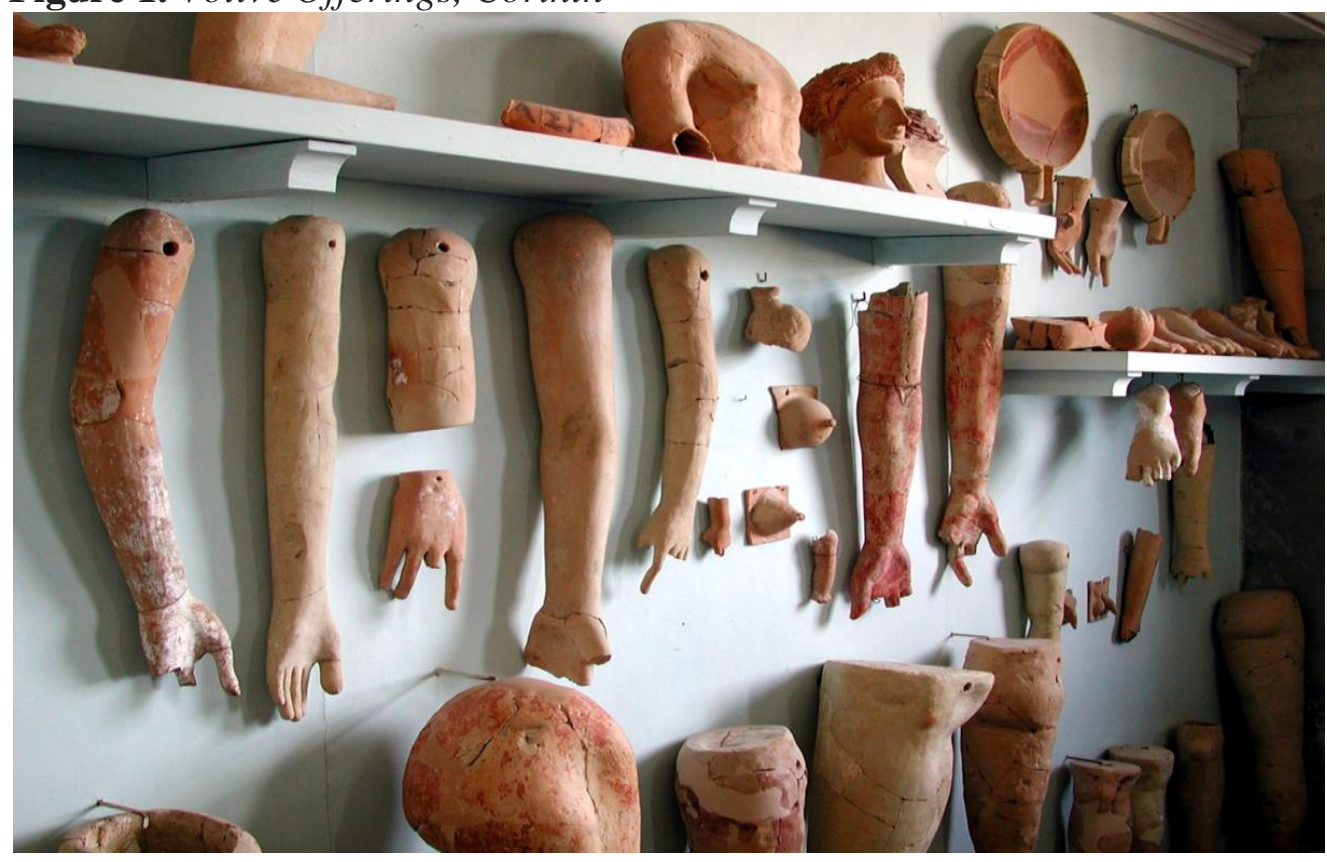

Figure 2. Votive Offerings of Breast and Penis, Corinth

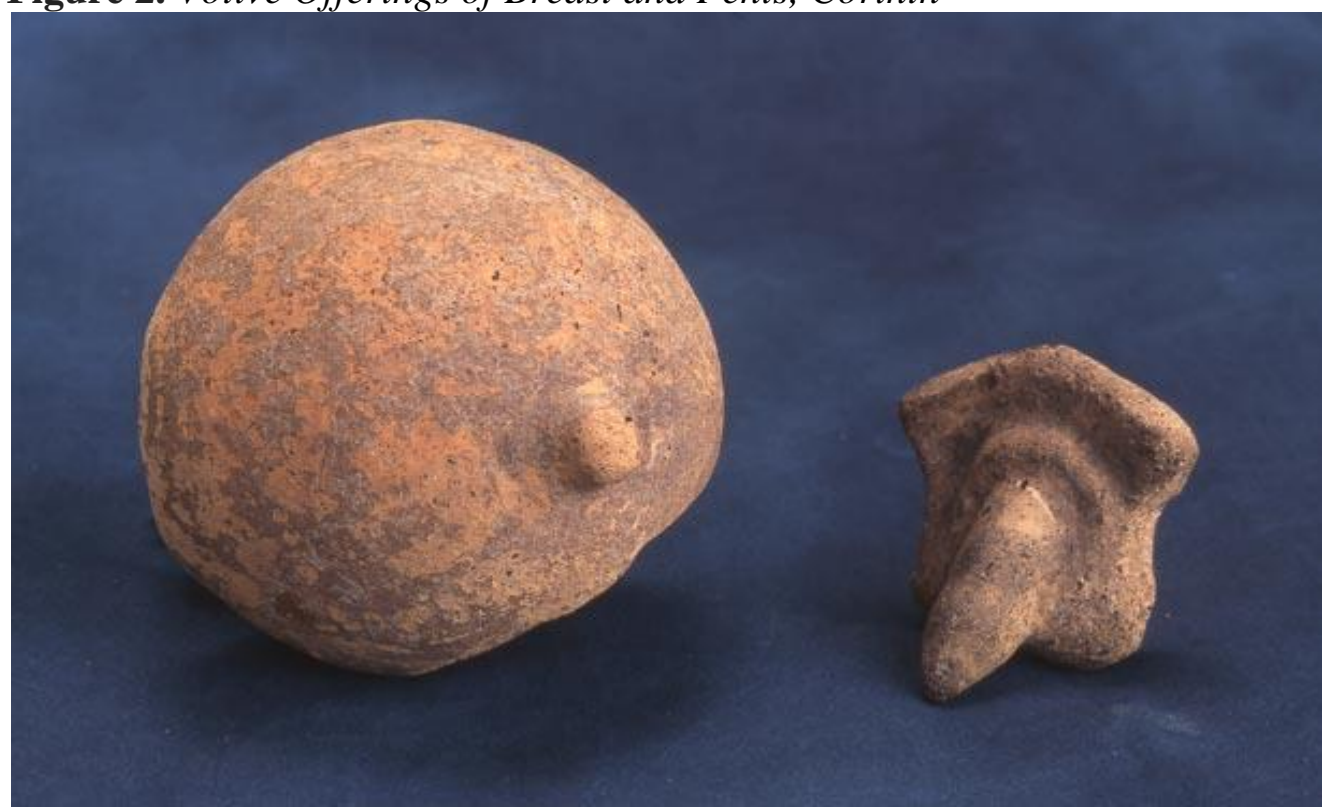

Among the Corinthian votives what we miss are representations of internal organs. There are two half torsos, but it is difficult to say what these may represent. The offering could involve an exterior ailment as easily as an internal one, or even something as non-problematic as bad posture. There are also heads, some fully portrayed, others partially; it may be best to imagine that the full heads denote general headaches, while the half-heads are meant to depict pain on one side of the head, that is, a migraine. 
Eye problems were a major concern at the center of Asclepius at Athens, which is located on the southwest slope of the Acropolis. ${ }^{1}$ Forty (40) percent of the votives, or 154, are eyes (Figure 3). Just as Corinth specialized in limbs and appendages as well as venereal disease, Athens seems to have been particularly well-known for curing ocular problems. In fact diseases associated with the head or parts of it seem to have been the overall specialty. Besides the 154 eyes, we have 25 ears (13 single ears, and six pairs) and 17 faces; the faces are harder to interpret, since the ailment could have been anything from skin ailments like pimples and acne to nasal conditions and the sinuses. There were two subspecialties at this cult center: feet and legs (41 legs: 34 single legs, and seven pairs; 12 feet), and sexuality (votives of male genitals and female genitals and breasts), although not to the same extent that we see at Corinth (Figure 4).

Figure 3. Votive Offering of Eyes, Athens

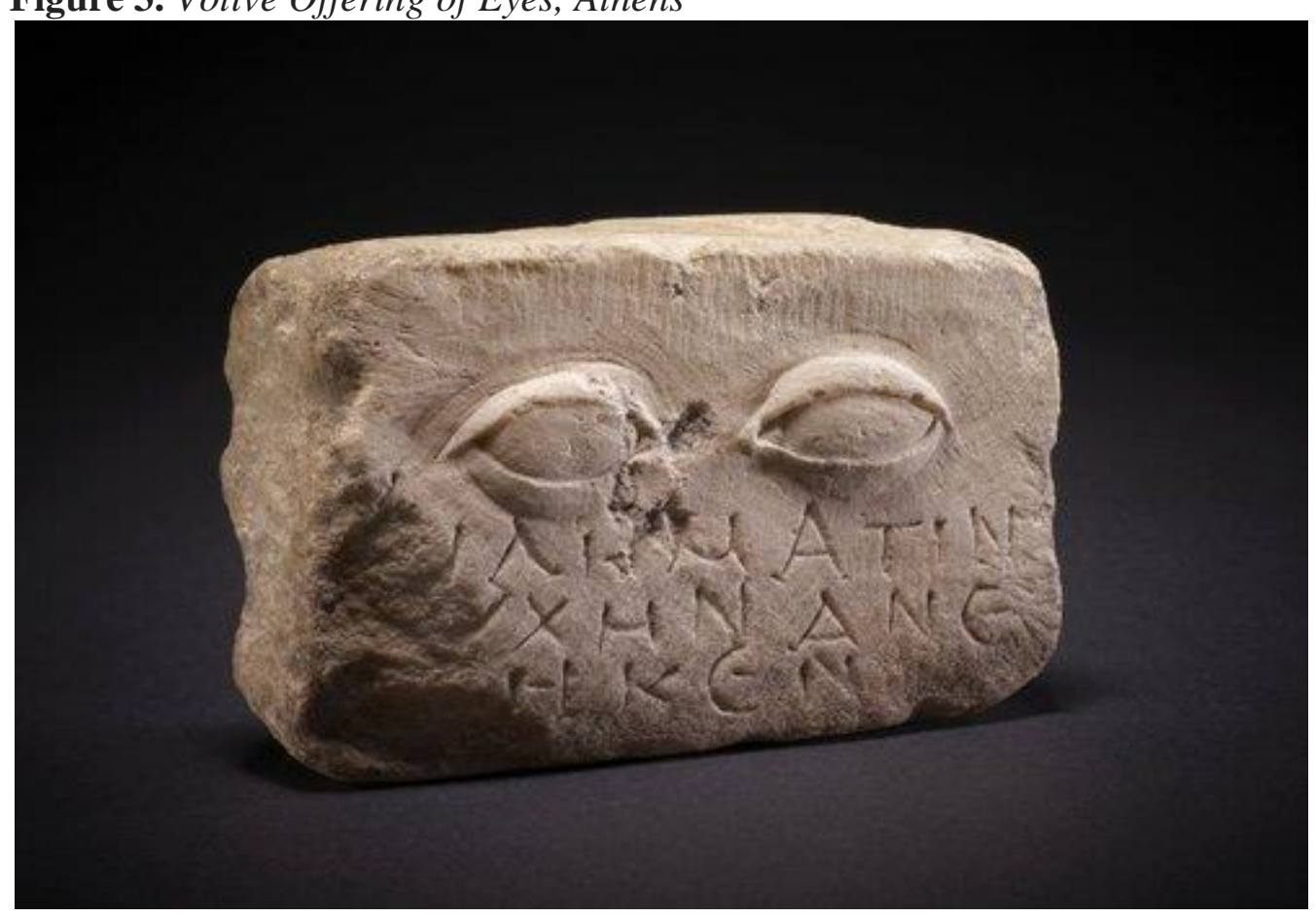

${ }^{1}$ Forsen (1996) and Rouse (1902, p. 212); cf. Chaviara-Karahaliou (1990) for parallels. At Corinth there are only three eyes, which would imply that people did not go there for treatment of that organ. 
Figure 4. Votive Offerings, Athens

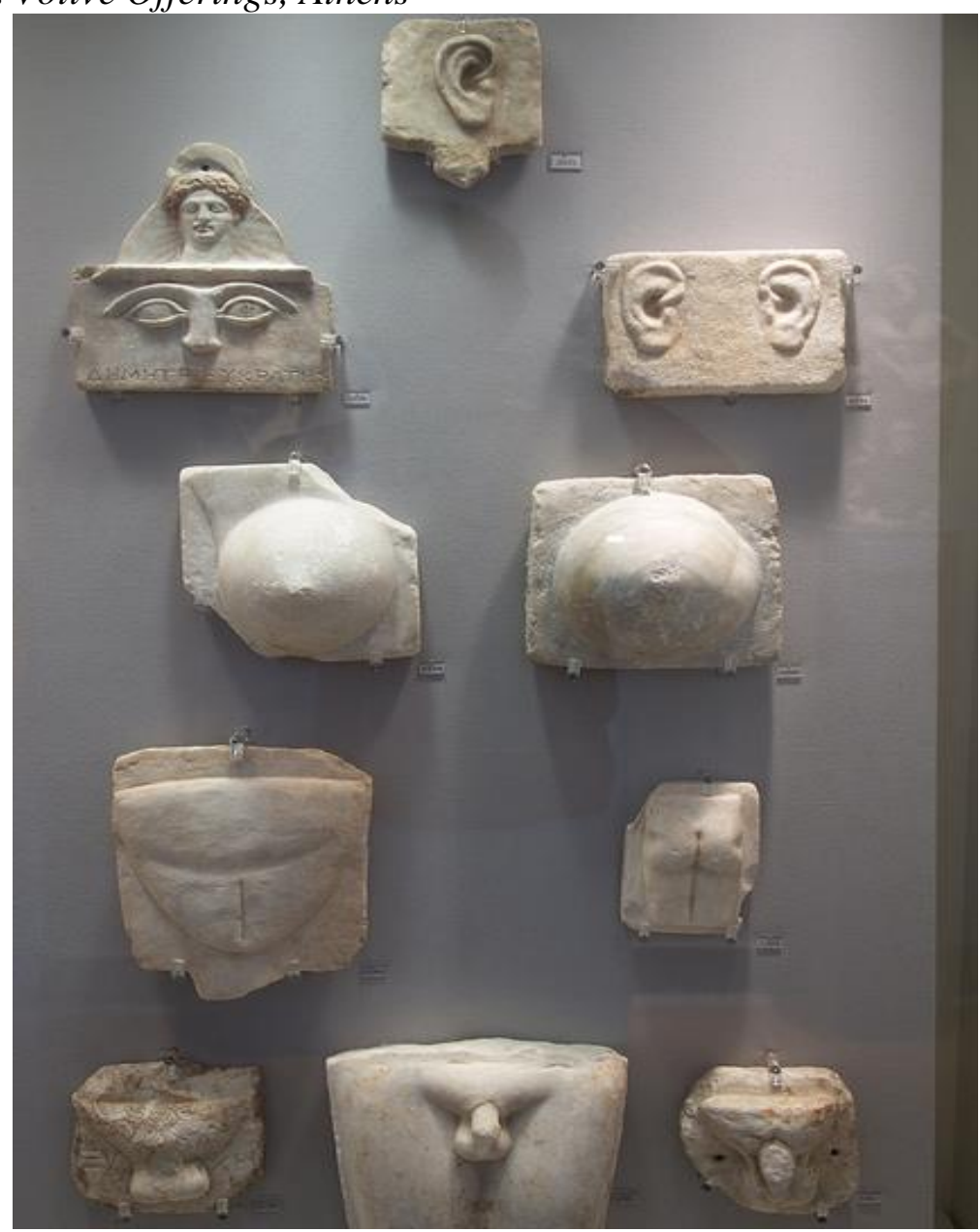

Not too far from the Athens sanctuary of Asclepius is the Sanctuary of Zeus Hypsistos on the Pnyx Hill. ${ }^{1}$ This place emphasized gynecological matters, as over 60 percent of the votive offerings are female breasts and female anatomy, including vulva and abdomen.

In northeastern Attica, about 23 miles east of Athens, is the sanctuary of Amphiareus, a mythical prophet and hero who later was worshipped as a god. ${ }^{2}$ At this sanctuary, patients, after sacrifices and ritual purification, laid down for the night in the stoa and was cured during their sleep. From the votive offerings the specialization of the sanctuary was lung and/or heart conditions. We have a large number of chests, and so cardiopulmonary problems seem to be indicated. ${ }^{3}$ The location of the sanctuary may have played a role in this specialization: the springs, wooded seclusion, and refreshing sea breezes would have rendered the site a spa.

When we move to the Italian healing sanctuaries, the healing specializations become even more clear. I would like to discuss a few

\footnotetext{
${ }^{1}$ See Parker (2005, p. 412) with full discussion and bibliography in note 100.

${ }^{2}$ See the excellent article of Petsalis-Diomidis (2006).

${ }^{3}$ Rouse (1902, p. 212).
} 
sanctuaries where the votive offerings are so high in number that we can comfortably reach conclusions about the medical problems that were dealt with at each sanctuary and about the people who visited that sanctuary.

\section{Ancient Italy}

At Ponte di Nona, about 10 miles east of modern Rome, a large sanctuary dedicated to an unknown deity was discovered. ${ }^{1}$ Anatomical votive offerings were found in two pits; one pit is inside the temple area, while the other was dug in a dump area north of the temple. Over 8,400 body parts have been recovered, and may be grouped into three major specialized areas of healing. Nearly three-quarters of the finds (nearly 6,000) are feet and hands, and arms and legs (Figure 5). In antiquity, this was a rural sanctuary and would have served an agrarian population. Given the profile of the people who came (peasants, farmers, laborers), it is not unexpected that we find limbs and appendages. Workers and farmers would have received many injuries, cuts, and contusions to their hands and arms, and feet can be bruised, ankles twisted, joints dislocated, and so forth, while toiling in fields. And of course a pedestrian, heavy walking lifestyle typified them as well. ${ }^{2}$ Indeed, the common foot ailments we treat easily today (fallen arches, ingrown toenails, torn ligaments, wounds, ulcerations, arthritic joints) were serious matters back in antiquity and posed dangers to the sufferer. The very high number of feet and legs (as well as hands and arms) as votive offerings at Ponte di Nona demonstrates that the people who came there were anxious for a cure and, evidently, found it.

\section{Figure 5. Votive Offering of Foot, Italy}

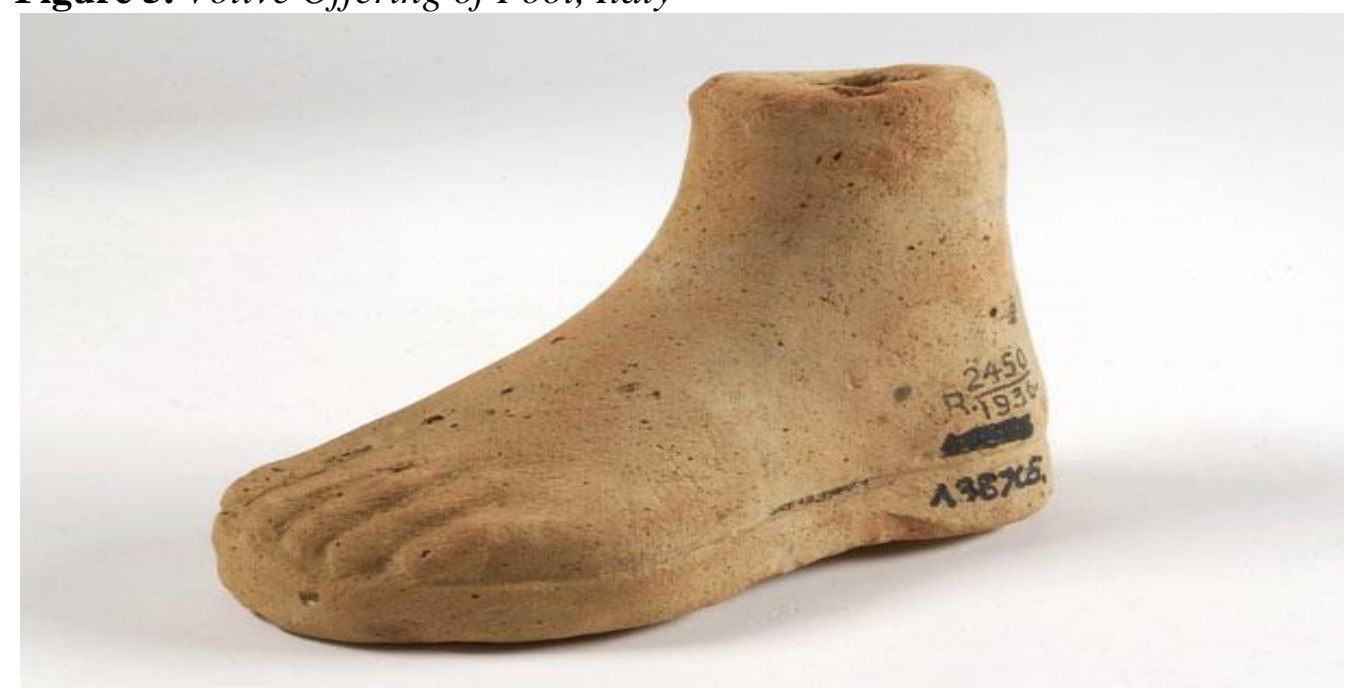

\footnotetext{
${ }^{1}$ The basic study is Potter and Wells (1985), who excavated the site. See now Griffith (2013) for the context.

${ }^{2}$ Potter $(1989,25,91)$.
} 
Two other rural Italian sanctuaries reveal a similar emphasis on limb injuries. At Fragellae over 4,000 votives have been recovered; of those, 1,654 are feet. ${ }^{1}$ At the so-called Thirteen Altars sanctuary at Lavinium, where the votives were placed on top of, and between, the altars, the majority were limbs: 207 lower limbs, 101 upper. Since we have only a few other body parts (ears, breasts, and the like) and no eyes or internal organs, the emphasis on limbs proves a specialization. ${ }^{2}$ Finally, at the Nemi rural sanctuary, there were a large number of limbs, again reflective of daily peasant life. ${ }^{3}$ This specialization is important because the sanctuary was dedicated to Diana, who was connected with childbirth and fertility. However, the votives dealing with babies or pregnancy are few, and so it is clear that at this particular sanctuary Diana could specialize in another field of healing.

Two other groups of offerings at Ponte di Nona are interesting. We have a large number of heads and half-heads; the most obvious reason is headaches and migraines (Figure 6). ${ }^{4}$ Cephalalgia has always been a major concern of Western medicine, and rural populations with long hours in the sun, lack of good nutrition, and poor living conditions have been afflicted with them. The excavators of Ponte di Nona suggest that the headaches may be attributed to local occurrences of malaria. Malaria was very common in western Italy and in low-laying coastal areas like Venice and Sicily, and remained so until the end of the nineteenth century. ${ }^{5}$ However, I am cautious about attributing to a headache the dedication of a head votive offering. A head may very well refer to a number of ailments beyond headache. In the discussions of head diseases in practical healing manuals, we have many head problems that have nothing to do with cephalalgia: lupus erythematosus, baldness, erysipelas, scabies, lichen planus, dandruff, eczema, scrofula, spots, warts, even hair loss. ${ }^{6}$ So, votive heads may reflect a wide range of problems related to the head.

A final area of specialization at Ponte di Nona is the eye. Over 1,000 eyes (singly or in pairs) were recovered (Figure 7). Some votives contain the eye with the eyelids and the periocular tissue, while others have just the eyeball. Thus, as scholars have pointed out, the sanctuary dealt with ailments that affect the eyelid and the eye both (e.g., conjunctivitis) and those that plague only the eye (e.g., myopia and cataract).

\footnotetext{
${ }^{1}$ Coarelli (1986).

${ }^{2}$ Castaglioni et al. (1975) for the excavations with Fenelli (1975) for analysis.

${ }^{3}$ For the cult see Hänninen (2000).

${ }^{4}$ But as Glinister $(2006,12)$ points out, heads may at times simply portray in some instances the worshipper.

${ }^{5}$ Majori (2012); if one were to juxtapose a map showing the areas of Italy with (historically) the worse patterns of malaria with a map of ancient Italian healing sites, there is a nearly perfect correlation.

${ }^{6}$ See, e.g., Papadogiannakês (2001, pp. 51-66).

${ }^{7}$ Jackson (1995, p. 2231).
} 
Vol. 1, No. 1 Oberhelman: Anatomical Votive Reliefs as Evidence for Specialization...

Figure 6. Votive Offering of Head, Italy

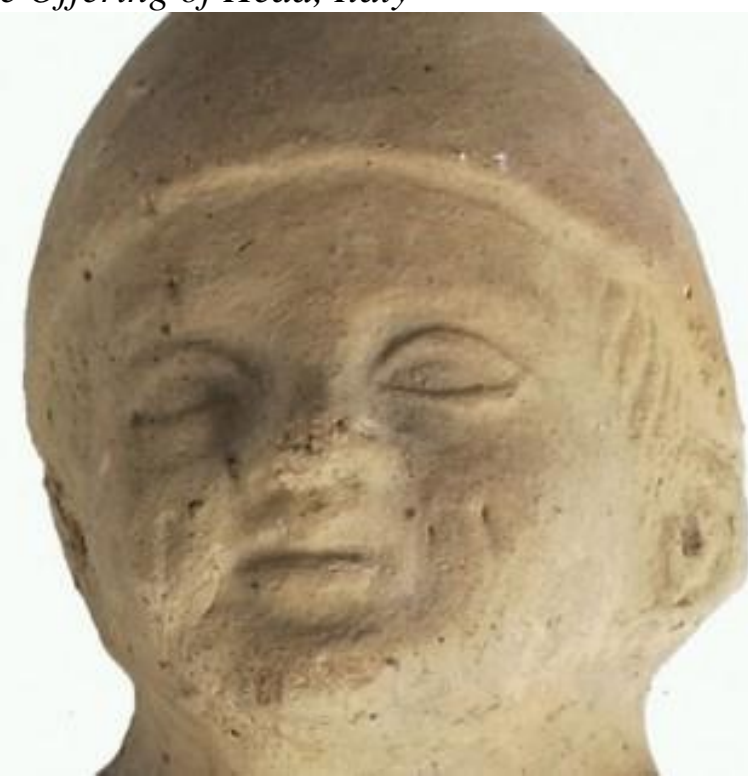

Figure 7. Votive Offerings of Eyes, Ears, and Foot, Italy

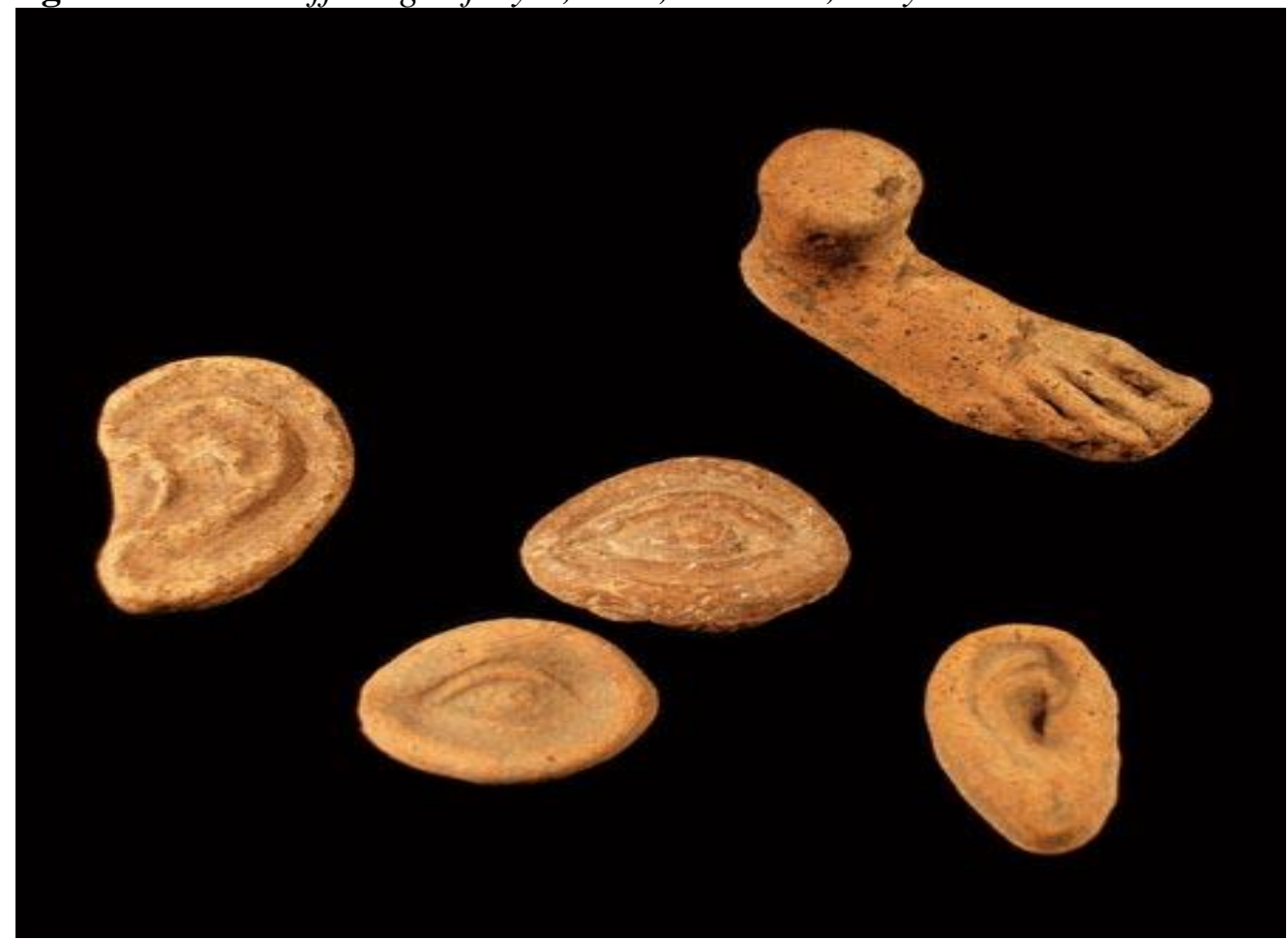

At Ponte di Nona there are conspicuously few sexual organs and internal organs. Obviously this does not mean that the local populace had no venereal disease or illnesses of the stomach, kidneys, and the like; rather, other sanctuaries took care of these problems. For example, at Campetti in Veii (10 miles north of modern Rome), we have a high number of sex organs, especially male genitalia. Votives of male genitalia could signify any number of ailments 
such as hernias and ureteral stones; but since many of them display phimosis, we are probably dealing with venereal disease, as it likely with an urban environment with brothels. ${ }^{1}$

Figure 8. Swaddled Baby and Sexual Organs, Italy

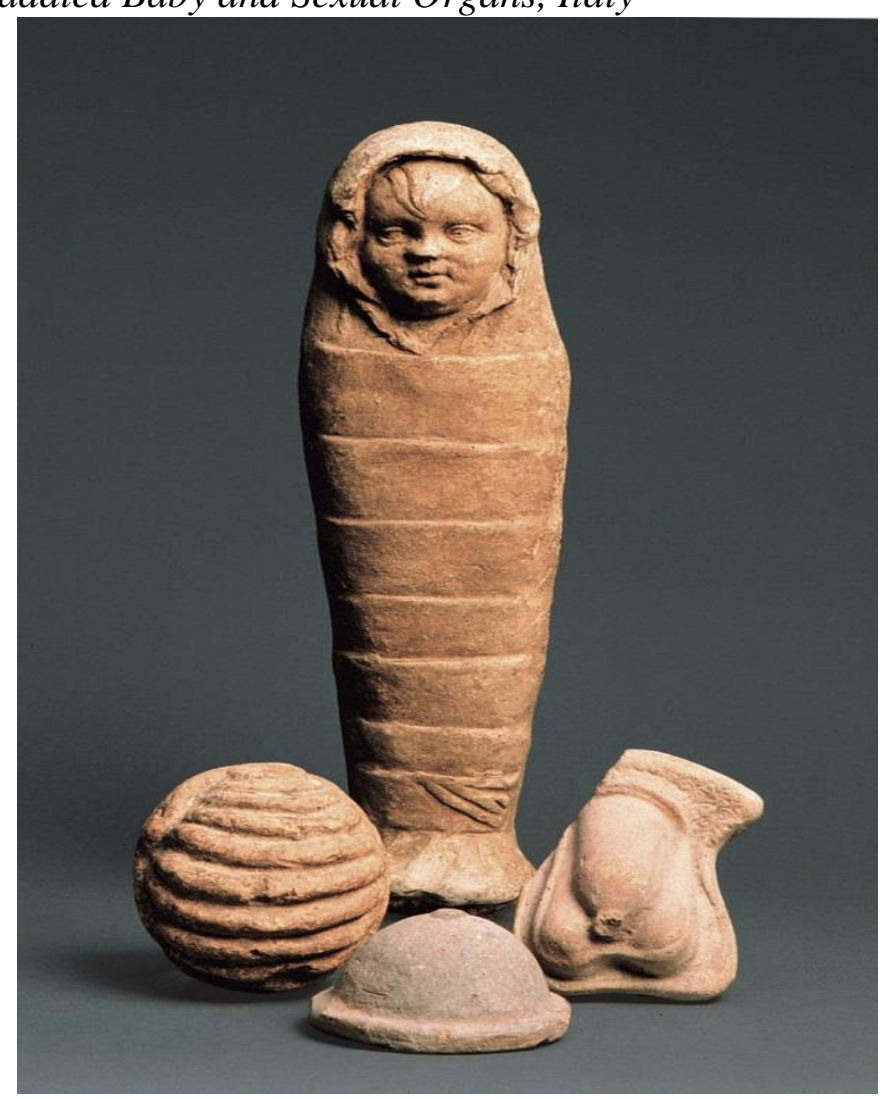

Female genitalia and breasts, as well as swaddled babies, are very frequent at other Italian sanctuaries (Figure 8). This proves an emphasis on female fertility and childbirth, since male genitals are at the same time scarce or nonexistent. At the religious center of Gravisca, which was the port city of Tarquinia, we have in one room alone of the religious complex 222 uteri. The goddess worshipped here was Uni (= Juno), who was in charge of fertility and infancy. The swaddled babies do not represent, in all likelihood, sick children, but a thanksgiving offering for a child delivered safely or even a wish for pregnancy. ${ }^{2}$ Another goddess in charge of fertility and safe pregnancy was Minerva (or Minvra). The votives at her sanctuary at Lavinium contains almost exclusively swaddled babies along with breasts and uteri. ${ }^{3}$ What do the uteri represent? The answer is fertilized wombs (Figure 9). When the uteri at the

${ }^{1}$ D'Arcy Dicus (2012, pp. 150-153). I would note that there are very few hand and foot votives at the Campetti sanctuary; this could reflect a less ambulatory and manual lifestyle of the visitors of the place or the existence of other healing centers in the city which took care of these problems.

${ }^{2}$ For the votives see Comella (1978).

${ }^{3}$ Turfa (1994, p. 82). 
sanctuary at Vulci (over 400 were discovered there) were subjected to x-ray, the films showed that nearly all contained small clay spheres, about 1 centimeter in diameter, thus denoting an embryo; some even had two spheres, thus denoting twins. ${ }^{1}$ Some uteri even have a small node or appendage on them; these may be interpreted as a tumor/cyst or ectopic pregnancy and the like.

Figure 9. Votive Offerings of Uteri, Subjected to X-Ray
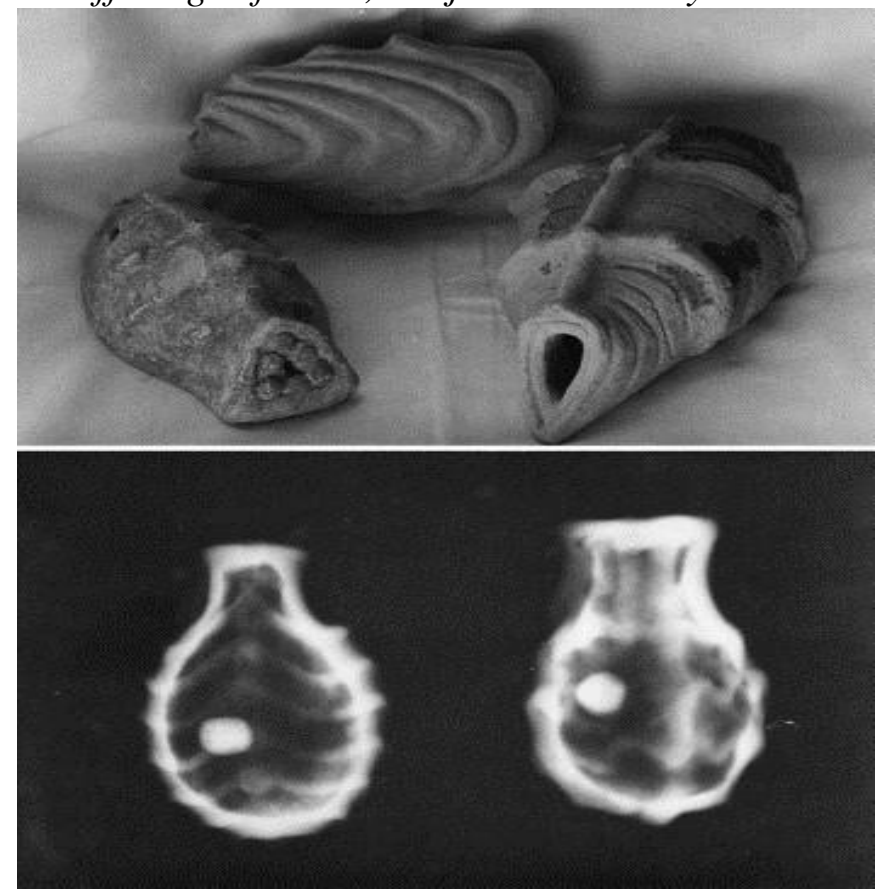

Although Juno was the main goddess in charge of fertility and pregnancy in Roman religion, she could specialize in other illnesses at her sanctuaries. At her cult center at Gabii there is an extremely high number of votive eyes and ears. Thus, even though Juno probably tended to gynecological matters at most of her sanctuaries, here at Gabii, people came for help for quite different problems.

\section{Discussion and Conclusion}

Before concluding, let me address the low number of votives that depict internal organs. Among the Greek votive offerings, we have but a few human internal organs portrayed. Does this mean that the healing sanctuaries were not interested in diseases that affected, for example, the stomach, intestines, liver, kidneys, and the like? This cannot be true, since we have many inscriptions and literary texts that detail cures of internal organs which the god Asclepius

\footnotetext{
${ }^{1}$ Baggieri (1998).
} 
performed. ${ }^{1}$ Also, the many chests at the Amphiareion prove that at least the heart and lungs were treated there, while certainly some of the torsos dedicated at Greek sanctuaries imply the healing of an internal organ. The reason why internal organs were not represented is that the Greeks did not have an accurate means of portraying them. Vivisection was not a Greek or Roman practice, and that dissection was not performed by Greek physicians until the third century B.C. (and then it was done in Alexandria in Egypt). ${ }^{2}$ In Italy we do have such representations of organs, specifically polyvisceral votive offerings, which display the trachea, heart, lungs, spleen, liver, and intestines (Figure 10). But medical experts have examined these representations and argue that they are not human, but animal. ${ }^{3}$ The votive viscera reproduce the innards of animals that were routinely butchered for food or that were cut open for sacrifice. The one exception to this is the votive relief of the uterus at the Italian sanctuaries. Scholars have noted that these are humanoid and have little in common with animal uteri; the accuracy in their depiction could only have come from direct observation. ${ }^{4}$ But when could the uterus have been observed? It was against Roman law to conduct dissection, and so the answer must be post-mortem Caesarean sections. ${ }^{5}$ By Roman law a pregnant women who died before delivery could not be buried until the fetus had been removed. The Caesarian removal of the fetus would have afforded a better understanding of the uterus that would otherwise have been impossible. Indeed, sometimes the uteri have surfaces studded with rounded knobs (probably to show fibroid tumors) or some abnormality (e.g., a uterus with two cervices). ${ }^{6}$

Anatomical votive offerings provide important evidence for the role of religious sanctuaries in medical healing in the ancient Mediterranean world. Most deities had the power to heal and give health, but they did so differently at their many sanctuaries. Suppliants seeking a cure for poor eyesight came to one temple on the grounds that here the god healed best; to another temple, someone afflicted with gonorrhea; and to another, someone suffering from an infected foot. The same deity worked wonders for sterile women at one sanctuary, but handled deafness at another cult center down the road. The votive offerings that have been recovered from the sanctuaries allow us to determine exactly how specialized many of the cult centers could be. Specialization is clearly evident when two adjacent sanctuaries reveal patterns of different body parts, and when a sanctuary does not show any proof of healing by the deity in her or his field of patronage. Case histories are not possible for the suppliants who dedicated these votive offerings, since the offerings were usually made from preset molds and likely mass produced. Occasionally we do have depictions of warts, varicose veins, tumors, and

\footnotetext{
${ }^{1}$ Van Straten (1981, p. 111): 'Ancient Greek votive offerings depicting internal organs are extremely rare, and as far as I know heart and bladder do no occur among the surviving examples.'

${ }^{2}$ See Von Staden (1992).

${ }^{3}$ Tabanelli (1960); but see D'Arcy Dicus (2012, p. 147) with his note 128 for bibliography.

${ }^{4}$ Turfa (1994, pp. 227-230) with notes and bibliography.

${ }^{5}$ I owe these sentences to Turfa $(1994,229-230)$.

${ }^{6}$ Ammerman (2002, pp. 325-329).
} 
broken (or rheumatoid) fingers; but typically all we have is a foot, which could imply anything from dropsy to paralysis to an ingrown toenail. Nevertheless, we can hypothesize to a reasonable degree about the kind of people who visited the sanctuaries and what illnesses they had hopes of being cured. We have, therefore, a database for information on ancient disease and healing which goes beyond the limited case histories in the Hippocratic writings and the medical texts of physicians like Galen, Celsus, and Aretaeus of Cappadocia.

Figure 10. Depiction of Viscera in Votive Offering, Italy

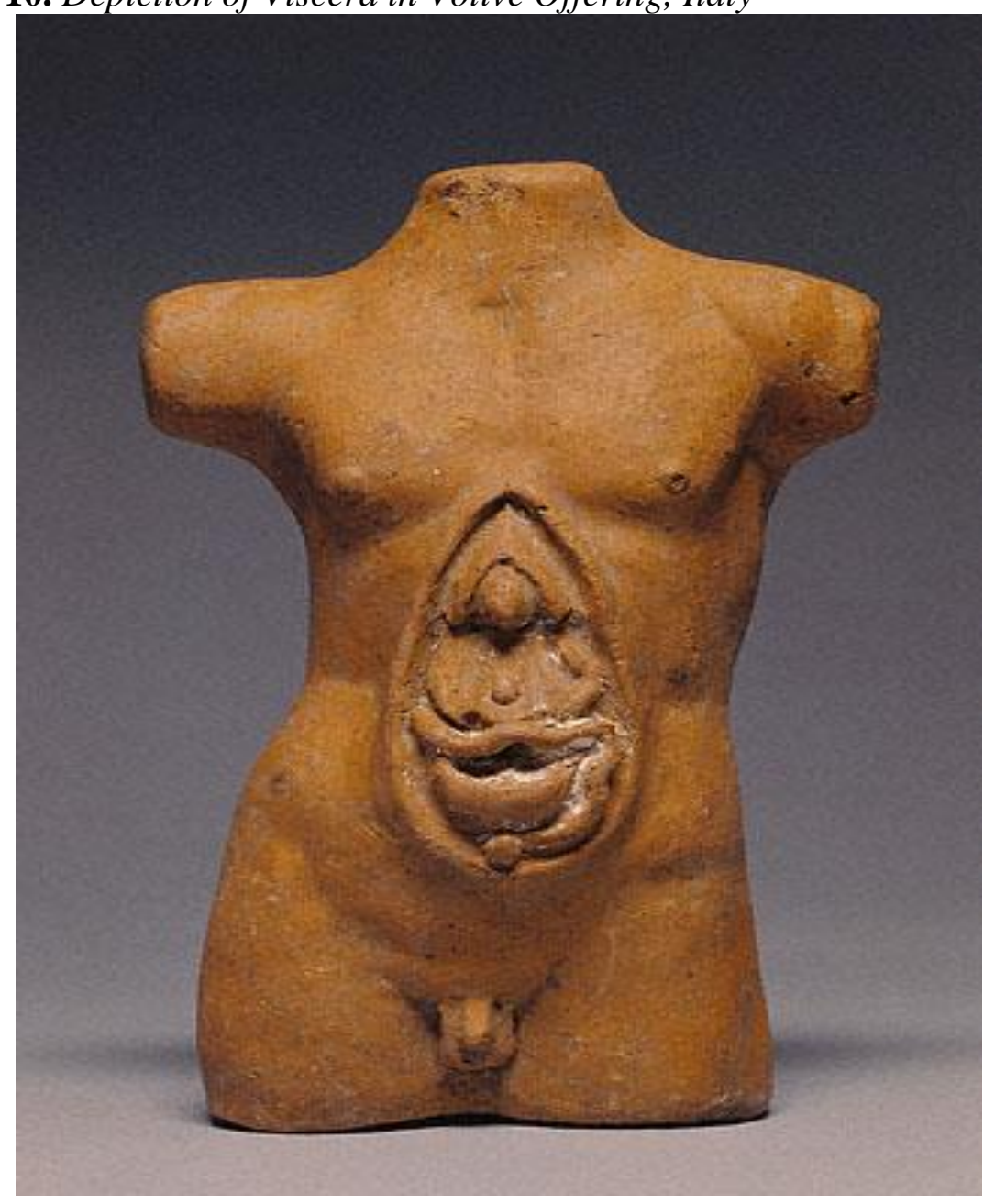

\section{Bibliography}

Aleshire, S. B. (1989). The Athenian Asclepeion: Their People, Their Dedications, and Their Inventories. Amsterdam: J.C. Gieben.

Ammerman, R. (2002). The Sanctuary at Santa Venera at Paestum, II: The Votive Offerings. Ann Arbor: University of Michigan Press.

Baggieri, G. (1998). 'Etruscan Wombs.' The Lancet 352: 790.

Bilbija, J. (2012). 'The Dream in Antiquity: Aspects and Analyses.' Ph.D. diss., Vrije Universiteit. 
Budin, S. (2008). The Myth of Sacred Prostitution in Antiquity. New York: Cambridge University Press.

Castagnoli, F., et al. (1975). Lavinium II: Le Tredici Are. Rome: De Luca.

Chaviara-Karahaliou, S. (1990). 'Eye Votives in the Asklepieion of Ancient Corinth.' Documenta ophthalmologica 135-139.

Comella, A. (1978). Il materiale votivo tardo di Gravisca. Rome: Giorgio Bretschneider.

Comella, A. (1981). 'Tipologia e diffusione dei complessi votive in Italia in epoca medio e tardo repubblicana: Contributo alla storia dell'artigianto antico.' Mélanges de l'École française de Rome 93: 717-803.

Coarelli, F. (1986). Fregellae, II: Il santuario di Esculapio. Pubblicazioni degli Istituti di Storia Antica e di Filologia Classica della Facoltà di lettere e filosofia, Perugia. Rome: Quasar.

Comella, A. (2001). Il santuario di Punta della Vipera. I materiali votivi. Corpus delle Stipi Votive in Italia XIII; Regio VII, 6. Rome: Giorgio Bretschneider.

D'Arcy Dicus, K. (2012). 'Actors and Agents in Ritual Behavior: The Sanctuary at Grasceta dei Cavallari as a Case-Study of the E-L-C Votive Tradition in Republican Italy.' Ph.D. diss., University of Michigan.

Fenelli, M. (1975). 'Contributo per lo studio del votivo anatomico: I votive anatomici di Lavinio.' Archeologia classica 27: 206-252.

Forsen, B. (1996). Griechische Gliederweihungen. Eine Untersuchung zu ihrer Typologie und ihrer religions- und sozialgeschichtlichen Bedeutung. Helsinki: Papers and Monographs of the Finnish Institute at Athens.

Glinister, F. (2006). 'Reconsidering Religious Romanization.' In C. Schultz and P. Harvey (eds.), Religion in Republican Italy, pp. 10-33. Cambridge: Cambridge University Press.

Griffith, A. (2013). 'Reconstructing Religious Ritual in Italy.' In J. D. Evans (ed.), A Companion to the Archaeology of the Roman Republic, 235-250. New York: Wiley.

Hänninen, M.-L. (2000). 'Traces of Women's Devotion in the Sanctuary of Diana at Nemi.' In J. R. Brandt et al. (eds.), Nemi-Status Quo: Recent Research at Nemi and the Sanctuary of Diana, pp. 45-50. Rome: L'Erma di Bretschneider.

Jackson, R. (1995). 'Eye Medicine in the Roman Empire.' In W. Haase and H. Temporini (eds.), Aufstieg und Niedergang der römischen Welt, part II, vol. 37.1, pp. 2228-2251. Berlin: Walter de Gruyter.

Lesk Blomerus, A. (1999). 'The Anatomical Votive Terracotta Phenomenon: Healing Sanctuaries in the Etrusco-Latial-Campanian Region during the Fourth through First Centuries B.C.' M.A. thesis, University of Cincinnati.

Majori, G. (2012). 'Short History of Malaria and Its Eradication in Italy with Short Notes on the Fight against the Infection in the Mediterranean Basin.' Mediterranean Journal of Hematology and Infectious Diseases. Available at http://www.mjhid.org/article/view/9990 [accessed 29 May 2013]

Oberhelman, S. M., ed. (2013). Dreams, Healing, and Medicine in Greece: From Antiquity to the Present. Surrey and Burlington, VT: Ashgate Publishing.

Papadogiannakês, N.E. (2001). A Cretan Iatrosophion of the $19^{\text {th }}$ Century. Rethymno: Historikê and Laographikê Hetaireia Rethymnês. [In Greek].

Parker, R. (2005). Polytheism and Society in Ancient Athens. Oxford: Oxford University Press.

Petsalis-Diomidis, A. (2006). 'Amphiaraos Present: Images of Healing Pilgrimage in Ancient Greece.' In R. Shepherd and R. Maniura (eds.), Images and 
Vol. 1, No. 1 Oberhelman: Anatomical Votive Reliefs as Evidence for Specialization...

Presence: Essays on the 'Presence' of the Prototype within the Image, pp. 205-229. London: Ashgate Publishing.

Potter, T. W., and C. Wells. (1985). 'A Republican Healing-Sanctuary at Ponte Di Nona near Rome and The Classical Tradition of Votive Medicine.' Journal of the British Archaeological Association 138: 23-47.

Potter, T. W. (1989). Una stipe votiva da Ponte di Nona. Roma: De Luca.

Roebuck, C. (1951). Corinth, Volume XIV: The Asklepieion and Lerna. Princeton: American School of Classical Studies at Athens.

Rouse, W. (1902). Greek Votive Offerings: An Essay in the History of Greek Religion. Cambridge: Cambridge University Press.

Söderlind, M. (2004). 'Man and Animal in Antiquity: Votive Figures in Central Italy from the 4th to 1st centuries B.C.' In B. Santillo Frizell (ed.), PECUS: Man and Animal in Antiquity: Proceedings of the Conference at the Swedish Institute in Rome, September 9-12, 2002, pp. 277-294. Rome: The Swedish Institute.

Steingräber, S. (1981). 'Zur Phänomen der etruskisch-italischen Votivköpfe.' Mitteilungen des Deutschen Archäologischen Instituts 87: 216-253.

Tabanelli, M. (1960). 'Conoscenze anatomiche ed ex voto poliviscerlai etruscoromani di Tessennano presso Vulci.' Rivista di Storia della medicina 2: 295313.

Turfa, J. M. (1994). 'Anatomical Votives and Italian Medical Traditions.' In R. D. De Puma and J. P. Small (eds.), Murlo and the Etruscans: Art and Society in Ancient Etruria, pp. 224-240. Madison: University of Wisconsin Press.

Van Straten, F. T. (1981). 'Gifts for the Gods.' In H. S. Versnel (ed.), Faith, Hope and Worship. Aspects of Religious Mentality in the Ancient World, pp. 65-151. Leiden: E. J. Brill.

Versnel, H. (2011). Coping with the Gods: Wayward Readings in Greek Theology. Leiden: E. J. Brill.

Von Staden, H. (1992). 'The Discovery of the Body: Human Dissection and its Cultural Contexts in Ancient Greece.' Yale Journal of Biology and Medicine 65: 223-241. 